\title{
Imaging Cobalamin Uptake within Malignant Breast Tumors In Vivo
}

\author{
Douglas A. Collins (1) \\ Department of Radiology, Mayo Clinic, Rochester, MN, USA
}

\begin{abstract}
Purpose: To image the uptake of cobalamin (Cbl) within malignant breast tumors in vivo.

Procedures: Prior to surgery 20 female patients with clinically suspected breast tumors were intravenously administered $0.25 \mu \mathrm{g}$ of an $\mathrm{In}-111$ labeled 5-deoxyadenosylcobalamin (AC) analog $\left(\left[{ }^{111} \mathrm{In}\right] \mathrm{AC}\right)$ and sequentially imaged with whole-body planar (WBP) and single-photon emission computed tomography (SPECT) between $2-5 \mathrm{~h}$ and $20-24 \mathrm{~h}$ post-injection (P.I.). The tumor to background (T/B) ratio for $\left[{ }^{111} \mathrm{In}\right] \mathrm{AC}$ in breast tumors at $2-5 \mathrm{~h}$ was correlated to its expression of estrogen (ER), progesterone (PR), and human epidermal growth factor 2 (HER2) receptors. Subsequent pulse chase (PC) experiments in nude mice burdened with the MDA-MB231 triple-negative (TN) breast tumor xenograft measured the effect that pulses of $A C$ or dexamethasone (DEX) had on $\left.{ }^{111} \mathrm{In}\right] \mathrm{AC}$ uptake in both normal murine tissue and the TN breast tumor.

Results: The mean $\left[{ }^{111} \mathrm{In}\right] \mathrm{AC}$ T/B ratio of the patients' 18 resected tumors was 5.8. Comparing ER- and PR-positive tumors $(n=11)$ to TN and HER2-positive tumors $(n=7)$, the mean $\left[{ }^{111} \mathrm{In}\right] \mathrm{AC}$ T/B ratios at 2-5 h P.I. were 3.2 (range 1.8-5.6) and 10.4 (range 3.3-22.5), respectively. Pulses of $2.0 \mu \mathrm{g}$ of $\mathrm{AC}$ at 2,8 , or $24 \mathrm{~h}$; or $40.0 \mu \mathrm{g}$ of DEX at $24 \mathrm{~h}$ prior to injecting $0.5 \mu \mathrm{g}$ of $\left[{ }^{111} \mathrm{In}\right] \mathrm{AC}$, increased mean tracer uptake in the MDA-MB-231 tumors by 26.4, 71.5, 92.6, and $49.1 \%$, respectively. Only the 2- and 24-h PC intervals concomitantly suppressed [ $\left.{ }^{111} \mathrm{In}\right] \mathrm{AC}$ uptake in normal murine tissue while enhancing $\left[{ }^{111}\right.$ In]AC uptake in MDA-MB-231 tumors.

Conclusion: The uptake of $\mathrm{Cbl}$ within malignant breast tumors can be imaged clinically. $\mathrm{Cbl}$ uptake is greatest in TN and HER2-positive breast tumors. A solitary bolus of AC or DEX increases the $\left[{ }^{111} \mathrm{In}\right] \mathrm{AC}$ uptake within a breast tumor in vivo. Investigating the cytogenetic mechanisms controlling the endocytosis of $\mathrm{Cbl}$ in malignant breast tumors is warranted.
\end{abstract}

Key words: Breast cancer, Cobalamin metabolism, Receptor imaging, Transport proteins, Genes

\section{Introduction}

The annual screening of women with mammography has contributed to the overall reduction in breast cancer mortality by increasing the early detection of clinically

Electronic supplementary material The online version of this article (https:// doi.org/10.1007/s11307-018-1232-9) contains supplementary material, which is available to authorized users.

Correspondence to: Douglas Collins; e-mail: collins.douglas@mayo.edu occult non-palpable breast tumors [1]. Depending upon a woman's ethnicity and breast tissue density, approximately 5 to $20 \%$ of breast tumors evade mammographic detection and clinically present as a palpable mass or metastatic lesion $[2,3]$.

Since the genetic and biochemical transformations occurring within a breast tumor ultimately construct the anatomic abnormalities perceived on mammography, molecular breast imaging (MBI) has gradually developed into a clinical tool capable of detecting aberrant metabolism within small 
malignant breast tumors [4]. The instrumentation of MBI, which includes positron emission mammography (PEM), single-photon mammography (SPM), and positron emission tomography/X-ray computed tomography (PET/CT), and the employment of these modalities in imaging the uptake of various metabolic tracers within breast tumors was recently reviewed $[5,6]$.

As a supplemental screening exam, both PEM and SPM have become effective tools in discovering mammographically and clinically occult non-palpable breast tumors in women with dense breast tissue [7]. If MBI is to ultimately function as a primary screening modality for pinpointing the early biochemical changes arising within an occult breast cancer, it must be paired with plasma and/or urine biomarkers indicating a metabolic pathway amenable to clinical imaging is aberrantly upregulated within a malignant breast tumor [8].

The cobalamin ( $\mathrm{Cbl}$ or vitamin B12) metabolic pathway was initially observed to be upregulated in mammary carcinomas shortly after the vitamin was discovered in 1948 [9]. Two of the proteins within the Cbl metabolic pathway were eventually found to be elevated in the serum of breast cancer patients [10, 11]. Cbl was ultimately discovered to have two co-enzymatic functions that uniquely support cellular proliferation. Within the cytoplasm, methylcobalamin (MC) is the co-enzyme for methionine synthase (MS). MS directly or indirectly supports cellular production of methionine, thymidine, and Sadenosylmethionine to sustain protein anabolism, DNA synthesis, and numerous methylation reactions, respectively. In the mitochondria, $5^{\prime}$-deoxyadenosylcobalamin $(\mathrm{AC})$ is the co-enzyme for methylmalonyl CoA mutase (MMCM). MMCM represents the final step in the catabolism of branched chain amino acids, odd chain fatty acids, and cholesterol. The end product succinyl-CoA supports energy production (ATP) and tetrapyrrole ring synthesis.

The increased uptake of $\mathrm{Cbl}$ within rapidly proliferating cells was initially depicted diffusely throughout fetal murine tissue in utero and selectively in transplanted mammary tumors in adult mice by $\mathrm{Co}-57$ labeled cyanocobalamin (CC) or $\left[{ }^{57} \mathrm{Co}\right] \mathrm{CC}$ (Fig. 1) and time-dependent autoradiography $[12] .\left[{ }^{57} \mathrm{Co}\right] \mathrm{CC}$ additionally assisted in deciphering that transcobalamin (TC) was the sole transport protein in serum to selectively bind and deliver $\mathrm{Cbl}$ to every tissue type in humans, that holo-TC (TC carrying a single molecule of $\mathrm{Cbl}$ ) underwent endocytosis by the dedicated transcobalamin receptor (TC-R) expressed on all human cell membranes [13], that holo-TC was primarily saturated with $\mathrm{AC}$ [14], and that $\mathrm{AC}$ was the major co-enzymatic form of $\mathrm{Cbl}(50-70 \%)$ in both normal and malignant human cells [15].

The upregulated expression of TC-R on tumor cell membranes, in association with a greater cytoplasmic concentration of $\left[{ }^{57} \mathrm{Co}\right] \mathrm{CC}$ bound to $\mathrm{TC}$ during DNA replication, initially established that the TC:TC-R pathway was the primary mechanism responsible for $\mathrm{Cbl}$ endocytosis in malignant tissue [16]. To directly investigate Cbl uptake in tumors by the TC:TC-R pathway, we previously described the synthesis and radiolabeling of an $\mathrm{AC}$ analog [17]. In vitro we demonstrated that both $\mathrm{TC}$ and intrinsic factor (IF), the Cbl transport protein uniquely secreted by gastric parietal cells to capture newly ingested $\mathrm{Cbl}$ in the proximal small bowel and deliver it to the cubilinamnionless (CUBAM) receptors expressed in the terminal ileum, both selectively bound and transported $\left[{ }^{111} \mathrm{In}\right] \mathrm{AC}$. In vivo $\left[{ }^{111} \mathrm{In}\right] \mathrm{AC}$ scintigraphically depicted the increased uptake of $\mathrm{Cbl}$ within transplanted human tumor xenografts in nude mice $[17,18]$, in naturally occurring feline and canine tumors diagnosed by veterinarians $[18,19]$ and in a variety of clinically suspected malignancies in patients [2022].

Here an In-111 radiolabeled $\mathrm{AC}$ analog or $\left[{ }^{111} \mathrm{In}\right] \mathrm{AC}$ (Fig. 1) was clinically employed to depict the uptake of $\mathrm{Cbl}$ within suspected breast tumors in 20 female patients. The tumor to background (T/B) ratio for $\left[{ }^{111} \mathrm{In}\right] \mathrm{AC}$ in breast tumor was correlated to its expression of estrogen (ER), progesterone (PR), and human epidermal growth factor 2 (HER2) receptors. Subsequent dose escalation (DE) and pulse-chase (PC) experiments were pursued in nude mice burdened with the human triple-negative (TN) breast tumor xenograft MDA-MB-231 to investigate our clinical observation of greater $\left[{ }^{111} \mathrm{In}\right] \mathrm{AC}$ uptake in the tumors of patients ingesting $\mathrm{Cbl}$ or dexamethasone (DEX) $24 \mathrm{~h}$ prior to [ ${ }^{111}$ In]AC administration [20, 21].

Summarized within is the $\left[{ }^{111} \mathrm{In}\right] \mathrm{AC}$ human and murine breast tumor imaging data, prior comparative investigations into $\mathrm{Cbl}$ uptake within normal and malignant breast tissue, and initial inquiry into potential genetic perturbations influencing the expression of the three $\mathrm{Cbl}$ transport proteins (transcobalamin, intrinsic factor, haptocorrin) and five $\mathrm{Cbl}$ receptor proteins (transcobalamin-R, megalin, cubilin, amnionless, asialoglycoprotein-R) within breast tumors.

\section{Materials and Methods}

\section{${ }^{111}$ In] AC Human Biodistribution Study}

The human $\left[{ }^{111} \mathrm{In}\right] \mathrm{AC}$ biodistribution study was approved by the Institutional Review Board at Mayo Clinic and the Federal Drug Administration and executed in accordance with the ethical standards delineated in the 1964 Helsinki Declaration. Informed consent was obtained from all individual participants prior to entering the study. A total of 20 female patients with clinically palpable or suspected underlying breast malignancies were enrolled from 1999 to 2005.

Prior to the intravenous (I.V.) administration of $\left[{ }^{111} \mathrm{In}\right] \mathrm{AC}$, a $5 \mathrm{ml}$ venous blood sample was acquired from all patients to establish a baseline $\mathrm{Cbl}$ plasma concentration. A maximum dose of $650 \mu \mathrm{Ci}$ of $\left[{ }^{111} \mathrm{In}\right] \mathrm{AC}$ was administered. The $\left[{ }^{111} \mathrm{In}\right]$ radiolabeling of the $\mathrm{AC}$ analog, calibration of the $\left[{ }^{111} \mathrm{In}\right] \mathrm{AC}$ dose syringe prior to and after I.V. administration, the $\left[{ }^{111} \mathrm{In}\right] \mathrm{AC}$ serum $\mathrm{T}_{1 / 2}$ 


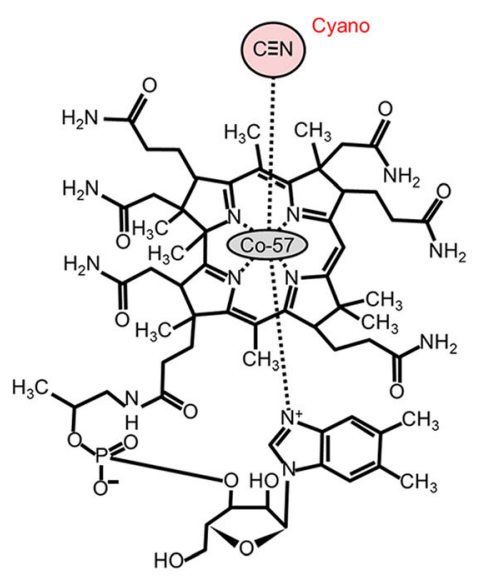

$\left[{ }^{57} \mathrm{Co}\right] \mathrm{CC}$

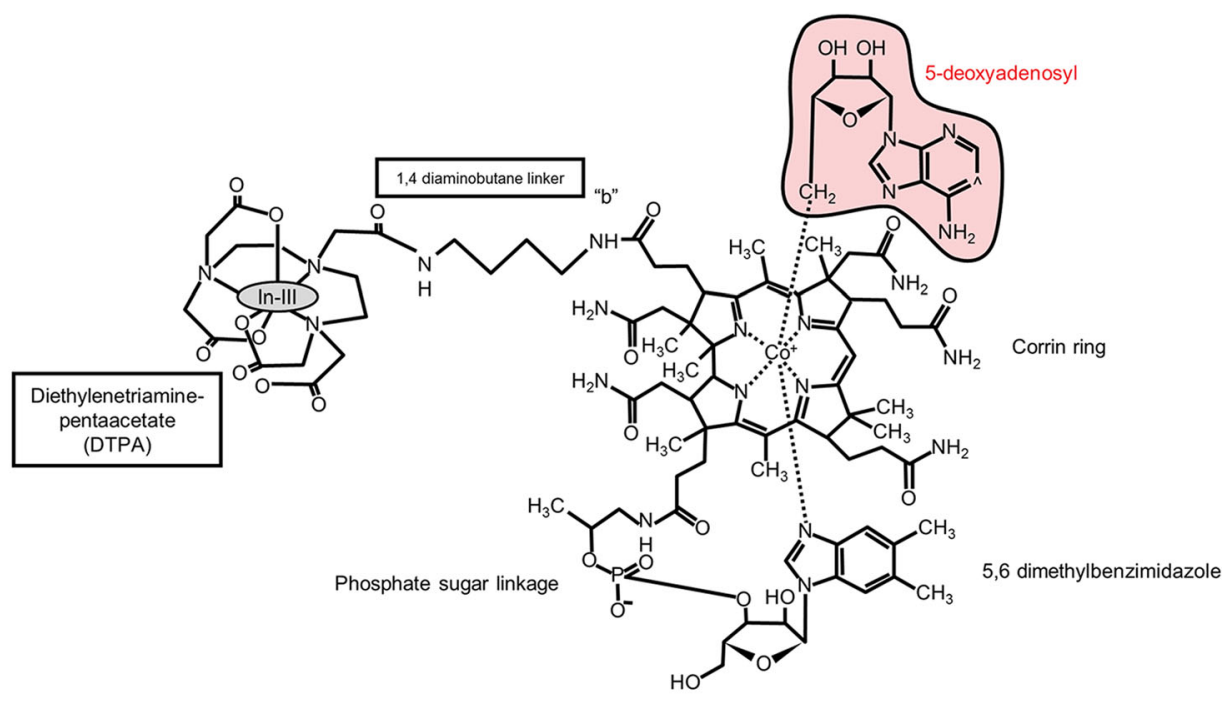

$\left[{ }^{111} \operatorname{In}\right] A C$
Co-enzyme forms of $\mathrm{Cbl}$

5-deoxyadenosylcobalamin (AC)

Methylcobalamin (MC)

Cbl transport proteins

Transcobalamin (TC)

Intrinsic factor (IF)

Haptocorrin (HC)
Cbl-dependent enzymes

Methylmalonyl-CoA-mutase (MMCM)

Methionine synthase (MS)

Cbl cell membrane receptor proteins

Transcobalamin (TC-R)

Megalin (MEG)

Cubilin-amnionless (CUBAM)

Asialoglycoprotein receptor (ASGP-R)

Fig. 1. Molecular structures of In-111-labeled 5-deoxyadenosylcobalamin ([111 In]AC) and Co-57-labeled cyanocobalamin $\left(\left[{ }^{57} \mathrm{Co}\right] \mathrm{CC}\right)$. Above the corrin ring are the $\beta$-ligands (5-deoxyadenosyl and cyano). Below is the $\alpha$-ligand 5,6 dimethylbenzimidazole (DMB) and the phosphate sugar that links DMB to the corrin ring. Summary of the biochemical names and abbreviations for the co-enzymatic forms of cobalamin (Cbl), Cbl-dependent enzymes, and dedicated Cbl transport and receptor proteins.

clearance assay, quantification of urinary excretion of $\left[{ }^{111} \mathrm{In}\right] \mathrm{AC}$, and the acquisition of the whole-body planar (WBP) and single-photon emission computed tomographic (SPECT) images were performed as previously described [20,21].

All patients were imaged prior to biopsy or breast surgery. The $\left[{ }^{111} \mathrm{In}\right] \mathrm{AC} \mathrm{T} / \mathrm{B}$ ratio of a breast lesion was calculated from the earliest acquired SPECT images (range $2-5 \mathrm{~h}$ ). Specifically, on coronal SPECT images, the $\left[{ }^{111} \mathrm{In}\right] \mathrm{AC}$ activity (counts per $\min$ or $\mathrm{CPM}$ ) in a breast tumors region of interest (ROI) was divided by the $\left[{ }^{111} \mathrm{In}\right] \mathrm{AC}$ activity from an ROI of normal breast tissue located in a correlative anatomic location of the contralateral breast. An $\left[{ }^{111} \mathrm{In}\right] \mathrm{AC} \mathrm{T} / \mathrm{B}$ ratio of 2.0 or greater was applied to delineate malignant from benign breast tissue $[23,24]$. A breast tumor $\left[{ }^{111} \mathrm{In}\right] \mathrm{AC} \quad \mathrm{T} / \mathrm{B}$ ratio was correlated to its reported expression of ER, PR, and HER2 receptors on post-surgical pathology.

\section{$\left[{ }^{111}\right.$ In] AC Murine DE and PC Experiments}

The Institutional Use and Animal Care Committee at Mayo Clinic approved the murine $\left[{ }^{111} \mathrm{In}\right] \mathrm{AC}$ DE and PC experiments. All applicable national guidelines for the care and use of animals were followed. Female nude mice (8-12 weeks old, 20-25 g) were inoculated with $1 \times 10^{6}$ MDA-MB-231 breast cancer cells in the dorsal cervical soft tissue. Once tumors reached $1.0 \mathrm{~cm}$ in size, mice in groups of five were studied per dose or time interval. A dose of $\left[{ }^{111} \mathrm{In}\right] \mathrm{AC}$ was injected via the intra-peritoneal (I.P.) route utilizing an insulin syringe with a 27 -g needle. The $\left[{ }^{111} \mathrm{In}\right] \mathrm{AC}$ DE experiments were pursued prior to the $\mathrm{PC}$ experiments to approximate the dose that the $\mathrm{AC}$ tracer would competitively inhibit its own uptake in normal murine tissue.

The DE experiments evaluated I.P. injections of $0.1 \mu \mathrm{g}$ $(240 \mu \mathrm{Ci}), 0.5 \mu \mathrm{g}(1200 \mu \mathrm{Ci})$, or $1.0 \mu \mathrm{g}(2400 \mu \mathrm{Ci})$ of $\left.{ }^{[111} \mathrm{In}\right] \mathrm{AC}(1.58 \mu \mathrm{g}$ of $\mathrm{AC}=1$ nmole of $\mathrm{AC})$. The $\mathrm{PC}$ 
experiments consisted of an initial I.P. pulse dose of $2.0 \mu \mathrm{g}$ of $\mathrm{AC}$ or $40 \mu \mathrm{g}$ DEX at 2,8 , or $24 \mathrm{~h}$ followed by an I.P. chase dose of $0.5 \mu \mathrm{g}\left[{ }^{111} \mathrm{In}\right] \mathrm{AC}$. All mice were euthanized by carbon dioxide asphyxiation at $24 \mathrm{~h}$ post $\left[{ }^{111} \mathrm{In}\right] \mathrm{AC}$ injection and immediately imaged on a clinical gamma camera (General Electric) with medium energy collimators. Normal tissue (brain, lung, heart, liver, spleen, left kidney, left quadriceps, left flank fat) and the MDA-MB-231 tumors were harvested and assayed for counts $/ \mathrm{min} / \mathrm{mg}$ tissue (CPM/ $\mathrm{mg}$ ) after the completion of imaging on all DE and PC experiments as previously described [17].

\section{Results}

\section{Imaging Cbl Uptake within Patient Breast Tumors}

All 20 women enrolled were Caucasian. Mean weight and age of the patients were $75.6 \mathrm{~kg}$ (range $58-103 \mathrm{~kg}$ ) and 53.9 years (range $35-80$ years), respectively. The mean $\mathrm{Cbl}$ plasma concentration was $595 \mathrm{ng} / \mathrm{l}$ (range 70-2000 ng/l). Normal range is $180-914 \mathrm{ng} / \mathrm{l}$. The mean injected dose of $\left[{ }^{111} \mathrm{In}\right] \mathrm{AC}$ per patient was $600 \mu \mathrm{Ci}$ (range $420-650 \mu \mathrm{Ci}$ ) or $\sim 0.25 \mu \mathrm{g}$ of the AC analog. Previously this was incorrectly reported as $2.2 \mu \mathrm{g}$ of $\mathrm{AC}$ analog [20, 21]. The error in dilution of the vials containing the $\mathrm{AC}$ analog was discovered during the $\left[{ }^{111} \mathrm{In}\right]$ radiolabeling for the murine experiments. Serum $T_{1 / 2}$ clearance was unchanged at $6.9 \mathrm{~min}$. Mean $24 \mathrm{~h}$ urinary excretion of $\left[{ }^{111} \mathrm{In}\right] \mathrm{AC}$ was $28 \%$ (range $13-42 \%$ ).

Of the 20 patients enrolled, one patient $(\mathrm{d} / \mathrm{h})$ was imaged and biopsied twice; initially prior to right mastectomy and 2 years post-mastectomy secondary to the development of new palpable metastatic disease. Therefore, a total of 21 suspicious breast lesions were investigated in 20 patients. The biodistribution of $\left[{ }^{111} \mathrm{In}\right] \mathrm{AC}$ is depicted in 14 of the women enrolled (Figs. 2, 3, and 4). Of the 21 suspicious breast lesions, 18 were malignant and 3 were benign (Table 1). Although both the WBP and SPECT images at $2-5 \mathrm{~h}$ depicted $\left[{ }^{111} \mathrm{In}\right] \mathrm{AC}$ uptake in $94.4 \%(17 / 18)$ of the suspected breast tumors, smaller breast tumors $(0.7-1.0 \mathrm{~cm})$ were better defined by SPECT. The WBP and SPECT images at 20-24 h did not improve the breast tumor T/B for [ ${ }^{111}$ In]AC (not shown).

The mean $\left[{ }^{111} \mathrm{In}\right] \mathrm{AC}$ T/B ratio of the 18 surgically resected malignant breast tumors was 5.8 (range 1.8-22.5). The $\left[{ }^{111} \mathrm{In}\right] \mathrm{AC}$ avid breast tumors were predominantly of high nuclear grade, invasive ductal carcinomas (IDC). However, $\left[{ }^{111} \mathrm{In}\right] \mathrm{AC}$ uptake was imaged within foci of high-grade ductal carcinoma in situ (DCIS), invasive lobular carcinoma, and an inflammatory breast cancer. Contrasting the uptake of $\left[{ }^{111} \mathrm{In}\right] \mathrm{AC}$ in aggressive TN and HER2 receptor-positive tumors (patients $\mathrm{d}, \mathrm{e}, \mathrm{f}, \mathrm{h}, \mathrm{i}, 1, \mathrm{q} ; n=7$ ) to ER- and PR-positive tumors (patients c, g, j, k, m, n, o, p, r, $\mathrm{s}, \mathrm{t} ; n=11$ ), the mean T/B ratios were 10.4 (range 3.3-22.5) and 3.2 (range 1.8-5.6), respectively.
Excluding one patient with a large $7.5-\mathrm{cm}$ breast tumor and three diffuse segmental breast cancers, the average size of the $\left[{ }^{111} \mathrm{In}\right] \mathrm{AC}$ avid breast tumors was $1.9 \mathrm{~cm}$ (range $0.7-3.4 \mathrm{~cm}$ ). The majority of patients with $\left[{ }^{111} \mathrm{In}\right] \mathrm{AC}$ avid breast tumors $(12 / 17)$ had not ingested $\mathrm{Cbl}$ or DEX $24 \mathrm{~h}$ prior to tracer administration. In this group of patients, the mean $\mathrm{T} / \mathrm{B}$ ratio was 3.5 (range 2.0-5.6) with a mean Cbl plasma concentration of 428 (range 70-580 ng/l). In the remainder of patients $(5 / 17)$ with $\left[{ }^{111} \mathrm{In}\right] \mathrm{AC}$ avid breast tumors that had ingested $\mathrm{Cbl}$ or DEX $24 \mathrm{~h}$ prior to $\left[{ }^{111} \mathrm{In}\right] \mathrm{AC}$ injection, the mean T/B ratio was 12.9 (range 5.9-22.5) with a mean Cbl plasma concentration of 1150 (range 710-2000 ng/l).

The one patient imaged twice was within this subgroup (d, f, h, i, q). Her TN breast tumor was associated with the greatest volume of metastatic disease, the two highest serum concentrations of $\mathrm{Cbl}$, the two greatest $\left[{ }^{111} \mathrm{In}\right] \mathrm{AC} \mathrm{T} / \mathrm{B}$ ratios, and the most urinary excretion of tracer $(42 \%)$ at $24 \mathrm{~h}$. Conversely, in the three true negative (TN) scans, and the one false negative (FN) scan (patient $\mathrm{t}$ ), the $\left[{ }^{111} \mathrm{In}\right] \mathrm{AC} \mathrm{T} / \mathrm{B}$ ratios were 1.3 (range 1.0-1.5) and 1.8, respectively. Mean $\mathrm{Cbl}$ plasma concentration in those four patients $(3 \mathrm{TN}+1$ FN) was 402 (range 350-488 ng/l).

Two patients $(\mathrm{m}, \mathrm{n})$ had $\left[{ }^{111} \mathrm{In}\right] \mathrm{AC}$ avid metastatic foci of breast tumor to the brain and retroperitoneal lymph nodes, respectively. Intriguingly, the $\left[{ }^{111} \mathrm{In}\right] \mathrm{AC} \mathrm{T} /$ $\mathrm{B}$ ratios in the metastatic lesions of patients $\mathrm{m}$ and $\mathrm{n}$ were 5.8 and 6.9 , respectively, compared to 2.8 and 3.2 in their primary breast tumors. In the only two patients $(f, n)$ undergoing both $\left[{ }^{111} \mathrm{In}\right] \mathrm{AC}$ SPECT and 2-deoxy-2$\left[{ }^{18} \mathrm{~F}\right]$ fluoro-D-glucose $\left(\left[{ }^{18} \mathrm{~F}\right] \mathrm{FDG}\right) \mathrm{PET} / \mathrm{CT}$ imaging, the uptake of $\left[{ }^{111} \mathrm{In}\right] \mathrm{AC}$ and $\left[{ }^{18} \mathrm{~F}\right] \mathrm{FDG}$ in the primary and metastatic foci of breast tumor were visually congruent despite injecting $0.6 \mathrm{mCi}$ of $\left[{ }^{111} \mathrm{In}\right] \mathrm{AC}$ compared to $15.2 \mathrm{mCi}$ of $\left[{ }^{18} \mathrm{~F}\right] \mathrm{FDG}$.

\section{Murine DE and PC Data}

Neither the 0.1 or $0.5 \mu \mathrm{g}$ bolus of $\left[{ }^{111} \mathrm{In}\right] \mathrm{AC}$ (twice the dose administered to patients) saturated $\left[{ }^{111} \mathrm{In}\right] \mathrm{AC}$ uptake in normal murine tissue or the MDA-MB-321 tumors. A $1.0 \mu \mathrm{g}$ bolus of $\left[{ }^{111} \mathrm{In}\right] \mathrm{AC}$ partially suppressed its own uptake in normal tissue (excluding the kidneys and lungs), while increasing mean $\left[{ }^{111} \mathrm{In}\right] \mathrm{AC}$ activity in the MDA-MB231 tumors by $35.1 \%$ (Table 2 ).

A 24-h PC interval between $\mathrm{AC}$ and $\left[{ }^{111} \mathrm{In}\right] \mathrm{AC}$ injections caused the greatest mean increase in $\left[{ }^{111} \mathrm{In}\right] \mathrm{AC}$ activity in the MDA-MB-231 tumors (92.6\%). A 24-h PC interval between DEX and $\left[{ }^{111} \mathrm{In}\right] \mathrm{AC}$ injections increased mean MDA-MB-231 tumor activity by $49.1 \%$. On both the AC and DEX 24-h PC intervals, the $\left[{ }^{111} \mathrm{In}\right] \mathrm{AC}$ activity in renal tissue increased $\sim 3.5$ and 4.3 times, respectively. $\left[{ }^{111} \mathrm{In}\right] \mathrm{AC}$ uptake in the 


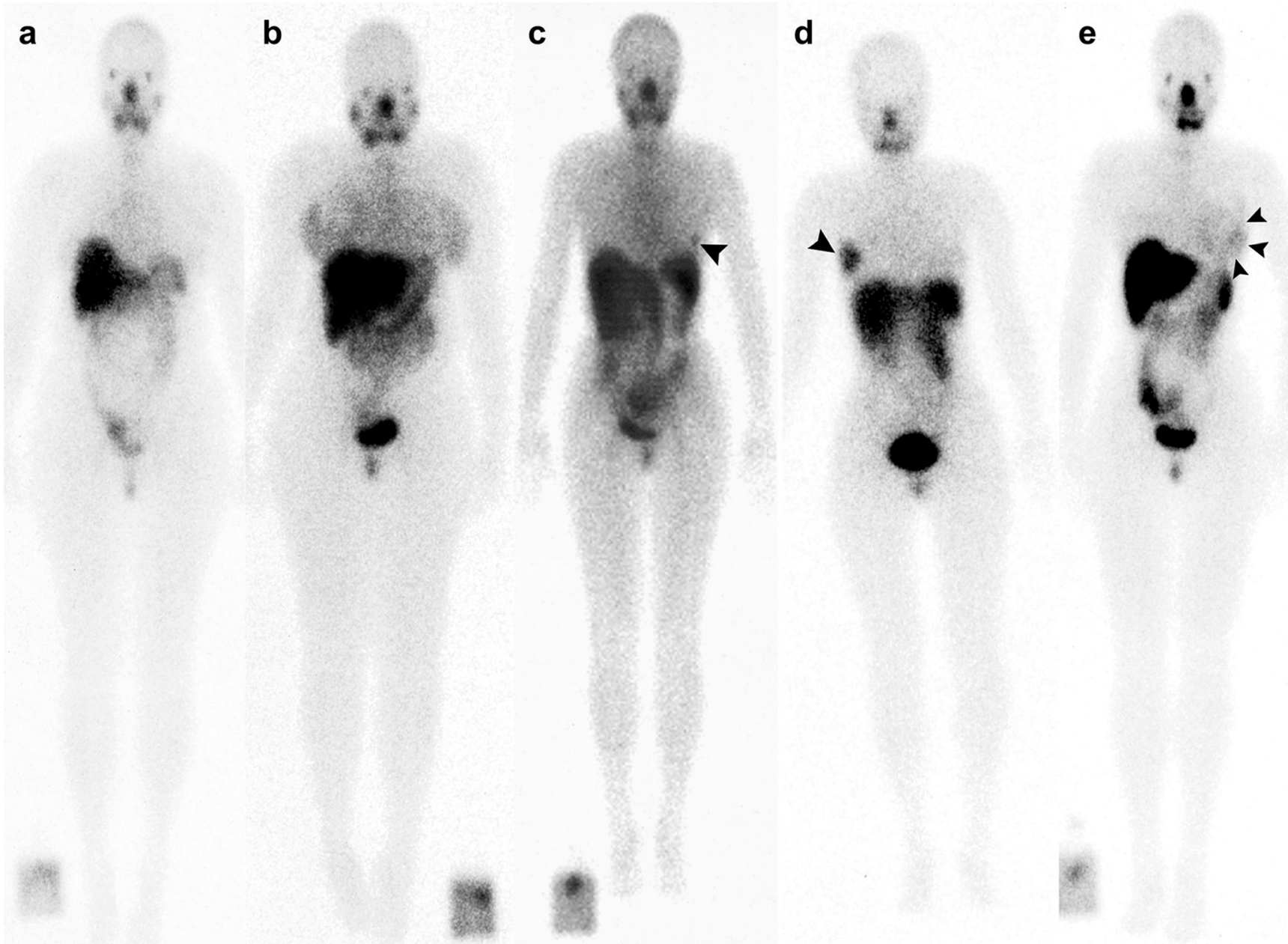

Fig. 2. a Patient 2 years post-resection of an invasive ductal breast cancer in the upper outer quadrant of the right breast. New palpable mass noted immediately superior to the surgical scar. No focal $\left[{ }^{111} \mathrm{In}\right] \mathrm{AC}$ activity within the breasts or axillae. $\mathbf{b}$ The only patient with bilaterally diffuse $\left[{ }^{111} \mathrm{In}\right] \mathrm{AC}$ activity in the breasts. The clinically large palpable mass in the right upper breast is photopenic with a mild rim of increased [ $\left.{ }^{111} \mathrm{In}\right] \mathrm{AC}$ activity. c Small $1.6 \mathrm{~cm}$ left breast cancer (black arrowhead) in the lower outer quadrant (4). d Large $7.5 \mathrm{~cm}$ right breast cancer (black arrowhead). The image was acquired at $0.5 \mathrm{~h}$ post [ $\left.{ }^{111} \mathrm{In}\right] \mathrm{AC}$ administration. e Diffuse $\left[{ }^{111} \mathrm{In}\right] \mathrm{AC}$ uptake in an inflammatory breast cancer involving the inferolateral left breast (three black arrowheads).

remainder of normal tissue was either not significantly changed or mildly suppressed.

Only the AC 2-h PC interval suppressed mean $\left[{ }^{111} \mathrm{In}\right] \mathrm{AC}$ activity in all normal tissue (excluding the kidneys), while concomitantly increasing mean $\left[{ }^{111}\right.$ In]AC activity in the MDA-MB-231 tumors by $26.4 \%$ (Table 2). Conversely, the AC 8-h PC interval uniquely caused the greatest mean increase in $\left[{ }^{111} \mathrm{In}\right] \mathrm{AC}$ activity in the majority of normal tissue (kidney, liver, fat, lung, skeletal muscle) and the second greatest mean increase of $\left[{ }^{111} \mathrm{In}\right] \mathrm{AC}$ activity $(71.5 \%)$ in the MDAMB-231 tumors.

The trend of greatest to least $\left[{ }^{111} \mathrm{In}\right] \mathrm{AC}$ avid tissue on the $\mathrm{DE}$ and $\mathrm{PC}$ experiments was consistently renal $>$ tumor $>$ liver $>$ fat $>$ lung $>$ spleen $>$ heart $>$ muscle $>$ brain. However, on the post mortem WBP images, only the kidneys, MDA-
MB-231 breast tumors and liver demonstrated any discernable $\left[{ }^{111} \mathrm{In}\right]$ AC activity (Fig. 5).

\section{Discussion}

Reported here is the largest cohort of female patients to have had Cbl uptake scintigraphically depicted within clinically suspected breast malignancies prior to surgery. The mean uptake of $\left[{ }^{111} \mathrm{In}\right] \mathrm{AC}$ in the 18 resected breast tumors was 5.8 times greater than in normal breast tissue. Although the limited number and bias selection of patients restricts any statistical conclusions, a pattern of $\left[{ }^{111} \mathrm{In}\right] \mathrm{AC}$ uptake was observed in the foci of suspected breast tumor.

First, the mean $\left[{ }^{111} \mathrm{In}\right] \mathrm{AC}$ T/B ratios were greater in biologically aggressive TN and HER2-positive breast tumors 

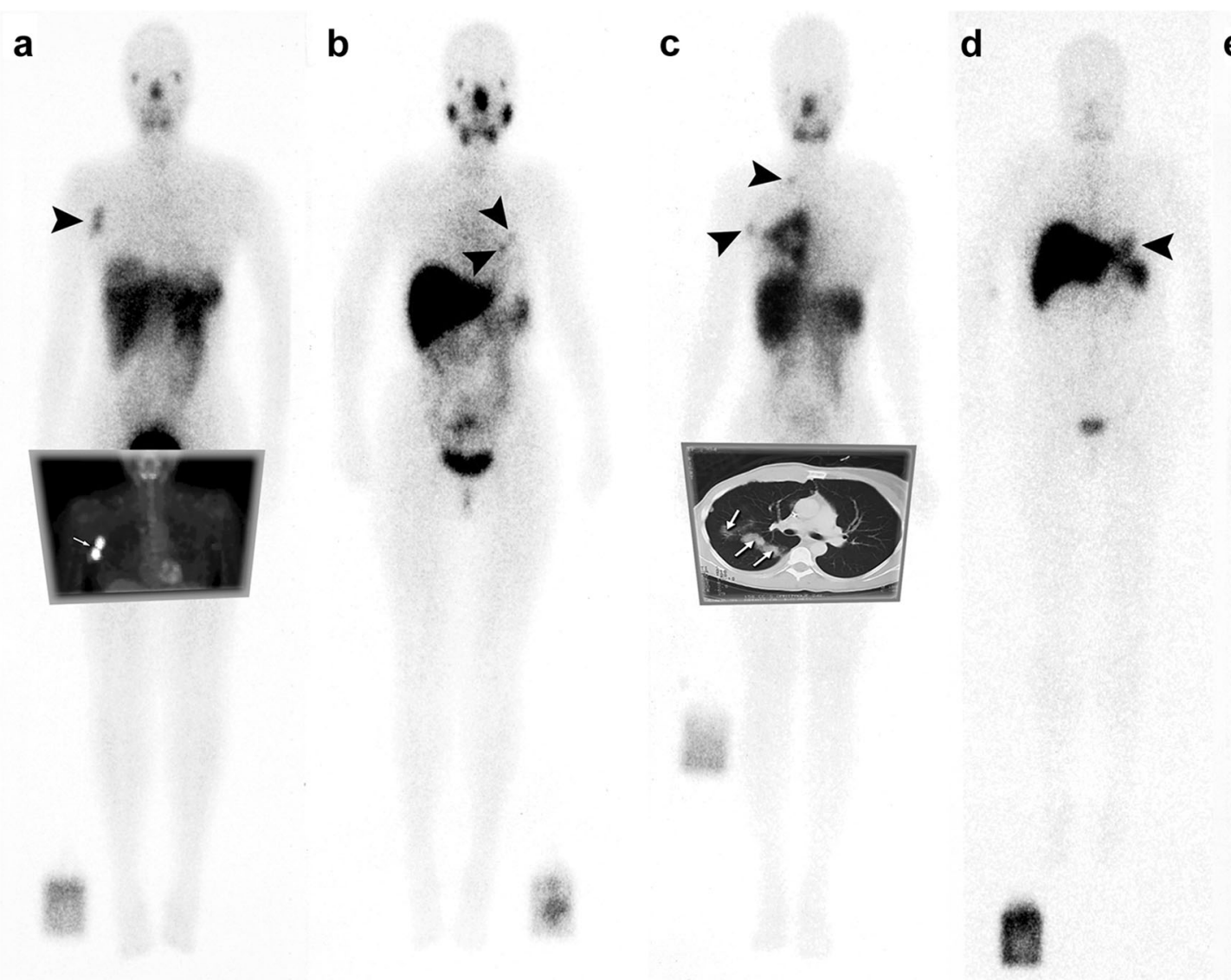

e

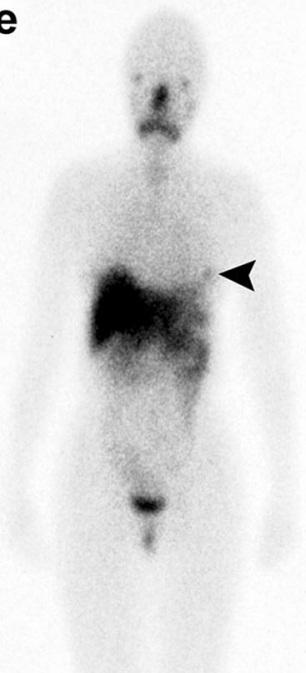

Fig. 3. a Focal $\left[{ }^{111} I n\right] A C$ activity in a right breast tumor and axillary lymph nodes (black arrow head). Corresponding $\left[{ }^{18} \mathrm{~F}\right] \mathrm{FDG}$ activity in the tumor and nodes on the inset $\left[{ }^{18} \mathrm{~F}\right] \mathrm{FDG}$ MIP image (white arrow). b Multifocal left breast cancer (black arrowheads) delineate two $(0.7$ and $0.9 \mathrm{~cm})$ of the three foci in the upper inner quadrant. A third focus was depicted by SPECT. c Two years after right mastectomy patient $d$ returns with new metastatic right supraclavicular and right axillary lymph nodes (black arrowheads). White arrows on the inset CT point to three of the multiple $\left[{ }^{111} \mathrm{In}\right] \mathrm{AC}$ avid pulmonary nodules in the right lung. d A $3.4 \mathrm{~cm}$ breast cancer in the inferomedial left breast (black arrowhead). e Small $0.9 \mathrm{~cm}$ left breast cancer in the lower outer quadrant (black arrowhead).

compared to ER- and PR-positive tumors. Second, metastatic foci of breast cancer could have greater $\left[{ }^{111} \mathrm{In}\right] \mathrm{AC} \mathrm{T} / \mathrm{B}$ ratios than their primary breast tumor. Third, the greatest $\left[{ }^{111} \mathrm{In}\right] \mathrm{AC} \mathrm{T} / \mathrm{B}$ ratios occurred in the breast tumors of patients with the highest serum concentrations of Cbl. This counterintuitive finding correlated to a patient's ingestion of $\mathrm{Cbl}$ or DEX $24 \mathrm{~h}$ prior to [ $\left.{ }^{111} \mathrm{In}\right] \mathrm{AC}$ administration.

The murine 24-h PC experiments confirmed the latter observation. The human and murine $\left[{ }^{111} \mathrm{In}\right] \mathrm{AC}$ imaging data additionally indicates that the capacitance for $\mathrm{Cbl}$ uptake in malignant breast tumors and normal tissue is differentially robust. Specifically, the recommended daily allowance (RDA) for Cbl in humans and mice is 2.4 and $0.1 \mu \mathrm{g}$, respectively $[25,26]$. With patients excreting an average of $28 \%$ of the $0.25 \mu \mathrm{g}$ dose of $\left[{ }^{111} \mathrm{In}\right] \mathrm{AC}$ into urine over a $24-\mathrm{h}$ interval, it was postulated that $\left[{ }^{111} \mathrm{In}\right] \mathrm{AC}$ uptake would rapidly become saturated in normal murine tissue and the MDA-MB231 tumors.
However, partial saturation of $\left[{ }^{111} \mathrm{In}\right] \mathrm{AC}$ uptake in normal murine tissue (excluding the kidneys and lungs) did not significantly occur until the $1.0 \mu \mathrm{g}$ bolus of $\left[{ }^{111} \mathrm{In}\right] \mathrm{AC}$. Even at that dose, which was four times the dose administered to patients and 10 times the murine RDA, no organ or tissue type was saturated greater than $67 \%$. That occurred in brain tissue. Conversely, $\left[{ }^{111} \mathrm{In}\right] \mathrm{AC}$ uptake in the MDA-MB-231 tumors and murine kidneys never reached saturation on either the DE or PC experiments.

Patient $\mathrm{d} / \mathrm{h}$ underscores the robust nature of $\mathrm{Cbl}$ uptake in an aggressive TN breast tumor. Her unique ingestion of supraphysiologic doses of vitamins as a sole therapeutic regimen, including 2000-5000 $\mu \mathrm{g}$ of $\mathrm{Cbl} /$ day, both multiple years prior to and in between her two episodes of $\left[{ }^{111} \mathrm{In}\right] \mathrm{AC}$ imaging, was associated with the highest $\left[{ }^{111} \mathrm{In}\right] \mathrm{AC}$ T/B ratios and two greatest concentrations of $\mathrm{Cbl}$ in serum.

Intriguingly, hepatic uptake of $\left[{ }^{111} \mathrm{In}\right] \mathrm{AC}$ in patient $\mathrm{d} / \mathrm{h}$, the primary site of $\mathrm{Cbl}$ storage in humans, was not suppressed compared to the cohort. The finding indicates 

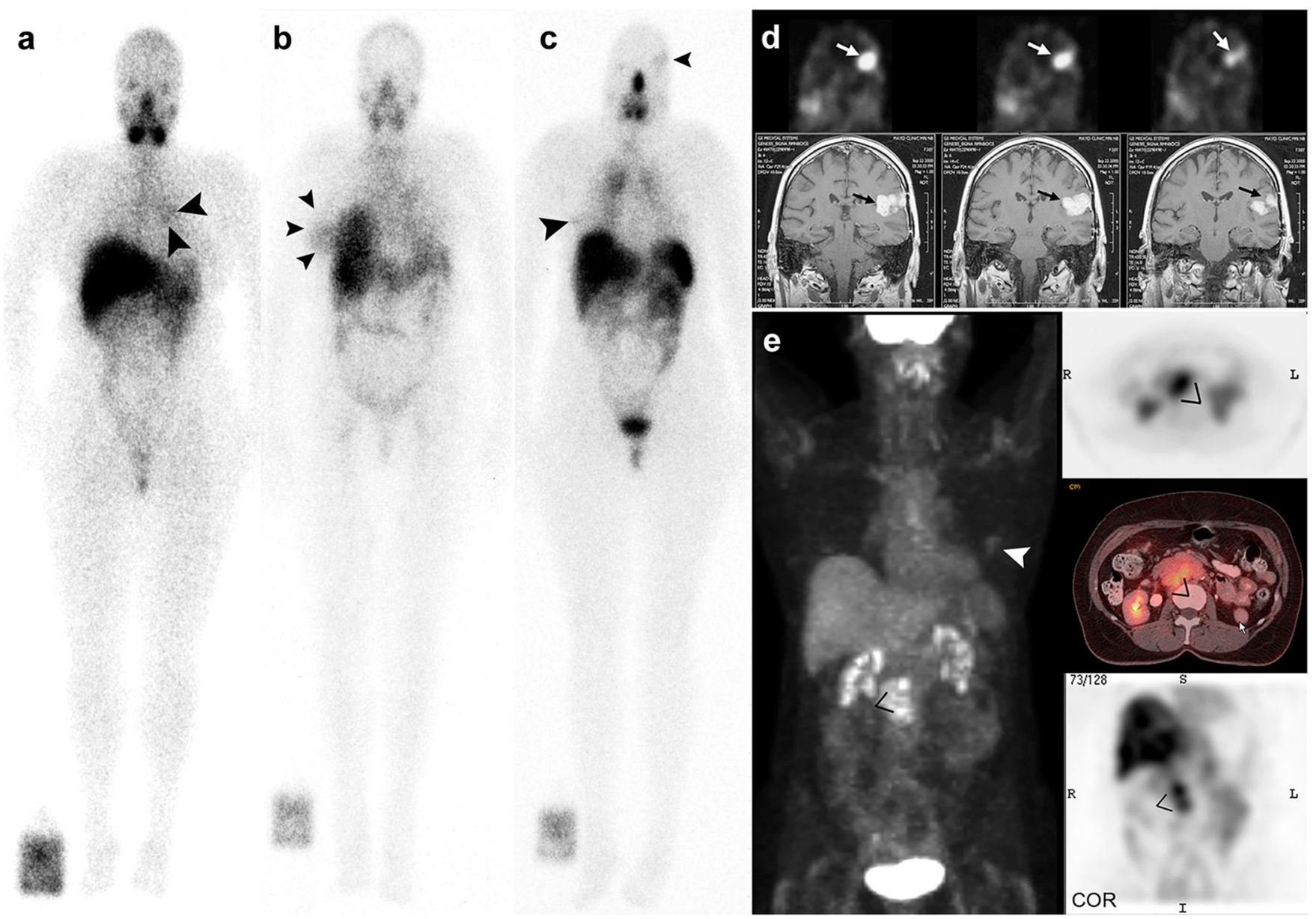

Fig. 4. a Small $1.2 \mathrm{~cm}$ left breast cancer in the upper inner quadrant (superior black arrow head). Increased background activity in the left hilum (inferior black arrowhead). b Diffuse $\left[{ }^{111} \mathrm{In}\right] \mathrm{AC}$ activity in the inferolateral right breast (three black arrowheads) corresponds to diffuse, multisegmental microcalcifications of invasive DCIS. Faint diffuse symmetric mediastinal activity (not delineated). c A small $0.7 \mathrm{~cm}$ right breast cancer (black arrowhead). Incidental diffuse bilateral hilar mediastinal $\left[{ }^{111}\right.$ In]AC activity. Focus of $\left[{ }^{111} \mathrm{In}\right]$ AC activity in the brain on the WBP images (black arrowhead) corresponds to $\mathbf{d}$ the adjacent three SPECT coronal images with metastatic breast cancer in the left cerebral hemisphere (white arrows). Immediately below are correlative coronal MRI images depicting the gadolinium enhancing metastatic breast tumor (black arrows). e The breast tumor (white arrowhead) on the MIP $\left[{ }^{18} \mathrm{~F}\right] \mathrm{FDG}$ images is less metabolically active than the retroperitoneal metastatic nodal disease (black "V" marker). Corresponding $\left[{ }^{111} \mathrm{In}\right] \mathrm{AC}$ coronal (COR) images with comparable activity in the retroperitoneal metastatic nodes (black "V" marker). Transaxial slice of the retroperitoneal nodal disease (black "V" marker) on both the colored $\left[{ }^{18} \mathrm{~F}\right]$ FDG PET/CT and the black and white $\left[{ }^{111} \mathrm{In}\right] \mathrm{AC}$ SPECT images.

that the capacitance for $\mathrm{Cbl}$ uptake in her liver and foci of primary and metastatic breast tumor were not saturated. Correspondingly, neither the MDA-MB-231 tumors or murine kidneys, the primary site of $\mathrm{Cbl}$ storage in mice, were saturated by the large doses of $\mathrm{AC}$ or $\left[{ }^{111} \mathrm{In}\right] \mathrm{AC}$.

\section{Potential PC Mechanisms Impacting Cbl Uptake in Breast Tumors}

A recent study observed that patients with chronic excess $\mathrm{Cbl}$ supplementation had the highest serum concentrations of holo-TC and sCD320 (the extracellular soluble component of TC-R). This subgroup of patients had Cbl serum levels greater than $1000 \mathrm{pmol} / 1$ [27]. It was posited that this subgroup of patients had developed an underlying increase in cellular metabolism and cell membrane TC-R activity that initiated an excess release of TC and $\mathrm{sCD} 320$ into the intravascular space.

The hypothesis may partially explain the elevated $\mathrm{Cbl}$ serum concentrations and greater breast tumor $\left[{ }^{111} \mathrm{In}\right] \mathrm{AC} \mathrm{T} /$ $\mathrm{B}$ ratios in the Cbl-supplemented patients. The findings imply that $\mathrm{Cbl}$ supplementation increased the endocytosis of $\left[{ }^{111} \mathrm{In}\right] \mathrm{AC}$ by upregulating TC-R expression on the cell membranes of a breast tumor. Conversely, the decreased $\left[{ }^{111} \mathrm{In}\right] \mathrm{AC}$ activity in patient $\mathrm{d} / \mathrm{h}$ lacrimal and salivary glands may exemplify how the chronic ingestion of $\mathrm{Cbl}$ suppresses its own uptake in normal tissue. 
Table 1. Patient $\left[{ }^{111} \mathrm{In}\right] \mathrm{AC}$ breast tumor imaging data and correlative pathology

\begin{tabular}{|c|c|c|c|c|c|c|c|c|c|c|}
\hline ID & Age & $\mathrm{Cbl}$ & Image & $\mathrm{T} / \mathrm{B}$ & NG & IG & ER & PR & HR & Surgical pathology \\
\hline $\mathrm{a}$ & 70 & 423 & $\mathrm{TN}$ & 1.0 & & & & & & Benign hamartoma, $1.8 \times 1.5 \times 0.6 \mathrm{~cm}$ right mass \\
\hline b & 36 & 488 & $\mathrm{TN}$ & 1.5 & & & & & & Ductal ectasia with periductal mastitis \\
\hline $\mathrm{c}$ & 59 & 491 & ТP & 3.9 & $2 / 3$ & $3 / 4$ & + & + & - & IDC, $1.6 \times 1.3 \times 1.1 \mathrm{~cm}$ left breast mass, $\mathrm{LN}$ \\
\hline $\mathrm{d}$ & 44 & 1278 & ТP & 22.5 & $2 / 3$ & $3 / 4$ & - & - & - & IDC, $7.5 \mathrm{~cm}$ fungating right breast mass, $\mathrm{LN}+$ \\
\hline $\mathrm{e}$ & 75 & 379 & ТP & 3.3 & $2 / 3$ & $3 / 4$ & + & - & + & Diffuse left inflammatory breast cancer, LN- \\
\hline $\mathrm{f}$ & 41 & 721 & $\mathrm{TP}$ & 5.9 & $3 / 3$ & $4 / 4$ & - & - & - & Right axillary tail mass $3.0 \times 2.4 \times 1.7 \mathrm{~cm} \mathrm{LN}+$ \\
\hline $\mathrm{g}$ & 58 & 420 & ТP & 3.9 & $2 / 3$ & $2 / 4$ & + & + & & IDC 0.7 and $0.9 \mathrm{~cm}$ solid papillary, $\mathrm{LN}^{-}$ \\
\hline $\mathrm{h}$ & 46 & 2000 & ТP & 14.8 & $3 / 3$ & $4 / 4$ & - & - & - & Poorly differentiated metastatic breast, $2.1 \mathrm{~cm} \mathrm{LN}+$ \\
\hline $\mathrm{i}$ & 35 & 710 & $\mathrm{TP}$ & 12.7 & $2 / 3$ & $4 / 4$ & - & - & - & IDC, $3.4 \times 3.0 \times 2.8 \mathrm{~cm}$ left breast mass, LN + \\
\hline j & 48 & 575 & $\mathrm{TP}$ & 3.4 & $2 / 3$ & $2 / 4$ & + & + & - & IDC, $0.9 \mathrm{~cm}$ left breast mass, $\mathrm{LN}^{-}$ \\
\hline $\mathrm{k}$ & 35 & 580 & $\mathrm{TP}$ & 2.5 & $2 / 3$ & $2 / 4$ & + & + & - & DCIS, comedo type, $1.2 \mathrm{~cm}$ left breast, $\mathrm{LN}^{-}$ \\
\hline 1 & 75 & 361 & TP & 5.2 & $2 / 3$ & $4 / 4$ & - & - & + & Segmental DCIS calcifications, $\mathrm{LN}^{-}$ \\
\hline $\mathrm{m}$ & 48 & 575 & $\mathrm{TP}$ & 2.8 & $2 / 3$ & $3 / 4$ & + & + & - & IDC, $0.7 \mathrm{~cm}$ right breast mass, left brain mets, $\mathrm{LN}^{-}$ \\
\hline $\mathrm{n}$ & 59 & 352 & ТP & 3.2 & $2 / 3$ & $3 / 4$ & + & + & & IDC, $1.8 \times 1.6 \mathrm{~cm}$ right breast mass, $\mathrm{LN}^{-}$ \\
\hline o & 60 & 437 & $\mathrm{TP}$ & 2.0 & $3 / 3$ & $4 / 4$ & - & - & & IDC, $0.8 \mathrm{~cm}$ mass in LUOQ, $15 / 22 \mathrm{LN}+$, \\
\hline $\mathrm{p}$ & 39 & 503 & $\mathrm{TP}$ & 5.6 & $2 / 3$ & $3 / 4$ & + & + & - & IDC, $1.9 \times 1.5 \times 1.2 \mathrm{~cm} \mathrm{LN+}$ \\
\hline q & 44 & 1041 & $\mathrm{TP}$ & 8.4 & $3 / 3$ & $4 / 4$ & + & - & + & IDC, $3.6 \times 3.4 \times 1.9 \mathrm{~cm}, \mathrm{LN}+$ \\
\hline r & 53 & 396 & $\mathrm{TP}$ & 3.5 & $2 / 3$ & $3 / 4$ & + & + & & Mixed lobular and ductal $1.2 \times 1.1 \times 0.7 \mathrm{~cm}, \mathrm{LN}-$ \\
\hline $\mathrm{s}$ & 58 & 70 & ТP & 2.1 & II & $4 / 4$ & + & + & - & Segmental invasive lobular CA, $\mathrm{LN}^{-}$ \\
\hline $\mathrm{t}$ & 71 & 350 & FN & 1.8 & $1 / 3$ & $1 / 4$ & + & + & & DCA tubular type, $0.9 \mathrm{~cm}$ mass, $\mathrm{LN}^{-}$ \\
\hline u & 63 & 347 & $\mathrm{TN}$ & 1.0 & & & & & & Fibrosis and giant cell reactions \\
\hline
\end{tabular}

$\mathrm{Cbl}$ cobalamin plasma concentration, $T P$ true positive, $T N$ true negative, $F N$ false negative, $T / B$ tumor to background ratio, $N G$ nuclear grade, $I G$ invasive grade, Breast tumor expression of ER estrogen receptor, $P R$ progesterone receptor, HR human epidermal growth factor 2 receptor, Positive (+), Negative (-), Borderline (-), IDC intraductal carcinoma, DCIS ductal carcinoma in situ, DCA ductal cancer, $L N$ axillary lymph node status for metastasis

Specifically, in mice subcutaneously administered $2.37 \mu \mathrm{g}$ of $\mathrm{CC} / \mathrm{h}$ for 4 weeks, a $50 \%$ reduction in both $\mathrm{TC}$ and TC-R transcription, and $\mathrm{Cbl}$ concentration occurred in the lacrimal and salivary glands [28]. It is reasonable to posit that the chronic ingestion of $\mathrm{Cbl}$ reduced $\left[{ }^{111} \mathrm{In}\right] \mathrm{AC}$ uptake in the majority of patient $\mathrm{d} / \mathrm{h}$ normal tissue and contributed to increasing her $\left[{ }^{111} \mathrm{In}\right] \mathrm{AC} \mathrm{T} / \mathrm{B}$ ratios and urinary excretion of tracer.

Precisely how a solitary bolus of AC or DEX enhanced $\left[{ }^{111} \mathrm{In}\right] \mathrm{AC}$ uptake in the MDA-MB-231 and patients breast tumors remains to be determined. Nevertheless, two prior human studies and the current murine $8 \mathrm{~h} \mathrm{PC}$ data indicate that the TC:TC-R pathway was acutely upregulated. Specifically, in patients given a solitary I.V. bolus of $0.2 \mu \mathrm{g}$ of CC/ $\mathrm{kg}$, the mean $\mathrm{TC}$ serum concentration was suppressed by $53.5 \%$ at $0.5 \mathrm{~h}$ post-injection, but gradually approached normal pre-injection levels by $8 \mathrm{~h}$ [29].
Correspondingly, female patients administered a single intramuscular injection of $120 \mathrm{mg}$ of DEX for two consecutive days had a mean $59 \%$ increase in TC serum concentration [30]. These studies imply that a large bolus of $\mathrm{Cbl}$ or DEX acutely triggers a cellular or endovascular release of apo-TC. Given that the $\mathrm{T}_{1 / 2}$ of TC-R renewal on cell membranes is $8 \mathrm{~h}$, the murine $8 \mathrm{~h} \mathrm{PC}$ data indicates that both a greater quantity of apo-TC in serum, and TC-R cell membrane expression augmented $\left[{ }^{111} \mathrm{In}\right] \mathrm{AC}$ endocytosis in normal murine tissue and the MDA-MB-231 tumors.

Recently, a novel immunohistochemical staining assay demonstrated that TC-R was overexpressed in MDA-MB231 tumors and that both TC-R and TC protein expression were markedly elevated in feline mammary carcinomas [31, 32]. The mean staining values for TC-R and TC in feline mammary tumors were 5263 and 5548, respectively, compared to 0.2 and 0.7 in normal peri-tumoral feline mammary tissue. The feline and MDA-MB-231 data

Table 2. In vivo uptake of $\left[{ }^{111} \mathrm{In}\right] \mathrm{AC}$ in MDA-MB-231 breast tumors and murine tissue

\begin{tabular}{|c|c|c|c|c|c|c|c|}
\hline & $\begin{array}{l}\mathrm{DE} \\
0.1 \mu \mathrm{g}\left[{ }^{111} \mathrm{In}\right] \mathrm{AC}\end{array}$ & $\begin{array}{l}\mathrm{DE} \\
0.5 \mu \mathrm{g}\left[{ }^{111} \mathrm{In}\right] \mathrm{AC}\end{array}$ & $\begin{array}{l}\mathrm{DE} \\
1.0 \mu \mathrm{g}\left[{ }^{111} \mathrm{In}\right] \mathrm{AC}\end{array}$ & $\begin{array}{l}\text { PC } \\
2.0 \mu \mathrm{g} \text { AC } 2 \mathrm{~h}\end{array}$ & $\begin{array}{l}\text { PC } \\
2.0 \mu \mathrm{g} \mathrm{AC} 8 \mathrm{~h}\end{array}$ & $\begin{array}{l}\text { PC } \\
2.0 \mu \mathrm{g} \mathrm{AC} 24 \mathrm{~h}\end{array}$ & $\begin{array}{l}\text { PC } \\
40 \mu \mathrm{g} \text { DEX } 24 \mathrm{~h}\end{array}$ \\
\hline Kidney & $169.8 \pm 20.9$ & $275.2 \pm 34.0$ & $875.2 \pm 118.2$ & $700.1 \pm 71.4$ & $1293.0 \pm 224.9$ & $970.3 \pm 115.5$ & $1187.5 \pm 173.4$ \\
\hline Tumor & $16.1 \pm 0.97$ & $75.7 \pm 5.4$ & $102.3 \pm 8.9$ & $95.7 \pm 7.6$ & $129.9 \pm 11.8$ & $145.8 \pm 13.3$ & $112.9 \pm 11.9$ \\
\hline Liver & $17.1 \pm 1.1$ & $75.7 \pm 5.2$ & $70.0 \pm 5.5$ & $44.9 \pm 3.1$ & $95.7 \pm 7.7$ & $78.5 \pm 7.2$ & $68.7 \pm 5.4$ \\
\hline Fat & $2.6 \pm 0.14$ & $35.8 \pm 2.9$ & $28.3 \pm 2.1$ & $31.6 \pm 2.3$ & $58.6 \pm 5.0$ & $40.0 \pm 3.6$ & $31.5 \pm 2.0$ \\
\hline Lung & $4.2 \pm 0.23$ & $26.3 \pm 2.4$ & $32.6 \pm 3.1$ & $24.2 \pm 1.9$ & $31.6 \pm 2.7$ & $28.8 \pm 2.6$ & $24.0 \pm 1.7$ \\
\hline Spleen & $5.3 \pm 0.29$ & $38.9 \pm 3.3$ & $23.2 \pm 1.7$ & $16.8 \pm 1.2$ & $26.6 \pm 2.0$ & $27.9 \pm 2.2$ & $30.2 \pm 2.8$ \\
\hline Heart & $2.1 \pm 0.09$ & $21.1 \pm 1.2$ & $17.4 \pm 1.3$ & $15.8 \pm 1.2$ & $22.1 \pm 1.0$ & $22.2 \pm 1.1$ & $22.3 \pm 1.2$ \\
\hline Muscle & $1.1 \pm 0.04$ & $10.5 \pm 0.5$ & $4.2 \pm 0.01$ & $4.1 \pm 0.01$ & $12.5 \pm 0.7$ & $9.8 \pm 0.4$ & $10.5 \pm 0.5$ \\
\hline Brain & $0.34 \pm 0.01$ & $3.6 \pm 0.12$ & $1.2 \pm 0.03$ & $1.3 \pm 0.03$ & $2.24 \pm 0.02$ & $2.3 \pm 0.02$ & $2.3 \pm 0.02$ \\
\hline
\end{tabular}

Dose escalation (DE). Pulse chase (PC). Rank order of the mean counts $/ \mathrm{min} / \mathrm{mg}$ tissue $(\mathrm{CPM} / \mathrm{mg}) \pm$ the standard deviation (SD) in CPM/mg. The reported $\mathrm{CPM} / \mathrm{mg}$ and SD values for each tissue type represents the actual counts acquired divided by 1000 


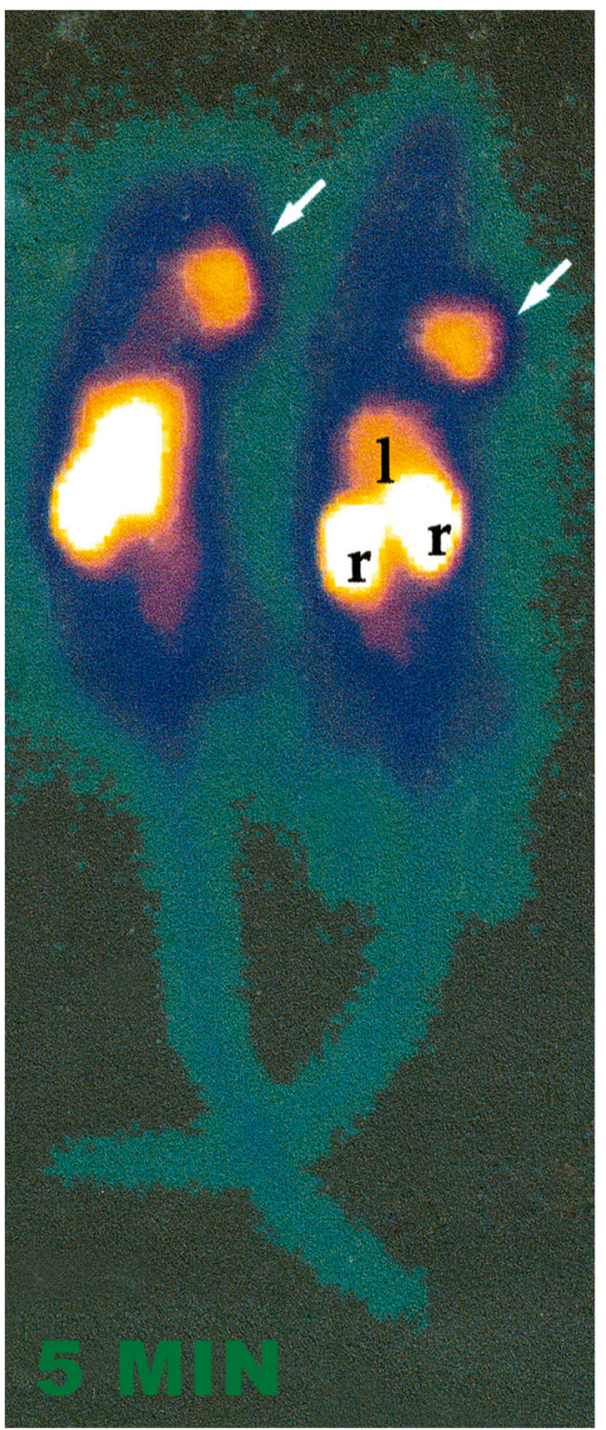

Fig. 5. Planar images of two mice employing a 2-h pulse chase interval between the $2.0 \mu \mathrm{g}$ AC pulse and $0.5 \mu \mathrm{g}$ $\left[{ }^{111}\right.$ In]AC injections. Image acquisition time at $24 \mathrm{~h}$ P.I. was 5 min. White arrows indicate $\left[{ }^{111} \mathrm{In}\right] A C$ uptake in the MDAMB-231 breast tumors in the cervical soft tissue. Typical liver (l) and renal $(r)\left[{ }^{111} \operatorname{In}\right] A C$ activity in mice.

indicates that the TC:TC-R pathway was primarily responsible for $\mathrm{Cbl}$ endocytosis in human and feline mammary carcinomas.

\section{Cbl Uptake in Breast Tumors Independent of the $T C: T C-R$ Pathway}

However, several murine and human studies have indicated that $\mathrm{Cbl}$ endocytosis within breast tumors can occur independent of the TC:TC-R pathway. For example, the Megalin (MEG) and CUBAM receptors have both been detected on human breast tumor cell membranes [33]. MEG is a crucial nutritional receptor that promotes cellular proliferation by facilitating the endocytosis of $\sim 50$ substrates, including holo-TC, holo-IF, folate, vitamin D, lipoproteins, sterols, hormones, insulin, and sonic hedgehog [34]. MEG can function either independently or in combination with CUBAM when the two receptors are colocalized in tissue. Not surprisingly, MEG and CUBAM receptors are variably expressed throughout embryonic and fetal tissues during development.

The importance of these receptors in supporting cellular proliferation was emphasized when antibodies directed against MEG and CUBAM, but not TC-R, caused fetal demise after their injection into pregnant mice [35]. Correspondingly, murine TC-R knock-out fetuses survived only until birth due to MEG maintaining maternofetal transport of $\mathrm{Cbl}$ in the visceral yolk sac and therefore $\mathrm{Cbl}$ uptake within fetal brain, spinal cord, and renal tissue in utero [36].

In contrast, the expression of MEG and CUBAM receptors in adult humans is essentially limited to tissue barriers that capture and reclaim Cbl. Specifically, CUBAM within the terminal ileum, and MEG-CUBAM or MEG alone in the vascular barriers within the renal proximal tubule, lacrimal/salivary glands, and the choroid plexus. It will therefore be important to investigate if $\mathrm{MEG}$ or CUBAM receptor expression occurs on the cell membranes and/or neo-vascularity of breast tumors.

Recently, the increased intracellular concentration of haptocorrin (HC) was reported in multiple tumor cell lines, including within lobular, ductal, and mucinous breast tumor cells [37]. Waibel et al. postulated that an upregulation in the expression of the asialoglycoprotein receptor (ASGP-R), which is responsible for the endocytosis of holo-HC, was the mechanism to affect the increased concentration of $\mathrm{HC}$ in tumor cells. Although the overexpression of ASGP-R mRNA was observed in murine fetal and newborn tissues [38], an assay to quantify ASGP-R expression on fetal or tumor cell membranes has yet to be reported.

To determine if the HC:ASGP-R pathway was more effective than the TC:TC-R pathway in imaging Cbl uptake in malignancies, Waibel et al. modified the molecular construct of $\left[{ }^{111} \mathrm{In}\right] \mathrm{AC}$. By shortening the amide linker covalently bonded to the "b" monocarboxylic acid of the corrin ring and substituting a monoanionic PAMA-ligand for the DTPA chelator, they reported that the new tracer $\left({ }^{99 \mathrm{~m}} \mathrm{TC}(\mathrm{CO})_{3}-[(4-\right.$ amido-butyl $)-$ pyridine-2-yl-methylaminoacetato]-cyanocobalamin) or $\left[{ }^{99 \mathrm{~m}} \mathrm{TC}\right] \mathrm{CC}$ was uniquely bound by $\mathrm{HC}$ and IF, but not by $\mathrm{TC}$. The finding was surprising since the selectivity of the transport proteins in binding biochemically active forms of $\mathrm{Cbl}$ is $\mathrm{IF}>\mathrm{TC}>>\mathrm{HC}$ [39]. Nevertheless, Waibel et al. reported that the in vivo uptake of $\left[{ }^{99 \mathrm{~m}} \mathrm{TC}\right] \mathrm{CC}$ was greater than $\left[{ }^{111} \mathrm{In}\right] \mathrm{CC}$ (not $\left.\left[{ }^{111} \mathrm{In}\right] \mathrm{AC}\right)$ in a syngeneic murine melanoma model.

Sah et al. subsequently enrolled 10 patients with various known tumors to compare $\left[{ }^{99 \mathrm{~m}} \mathrm{TC}\right] \mathrm{CC}$ SPECT/CT to $\left[{ }^{18} \mathrm{~F}\right] \mathrm{FDG} \mathrm{PET} / \mathrm{CT}[40]$. In the only breast cancer patient studied, the primary breast tumor had been resected prior to 
imaging. Of the multiple $\left[{ }^{18} \mathrm{~F}\right] \mathrm{FDG}$ avid metastatic foci of breast cancer depicted by PET/CT, only one lesion was detected by $\left[{ }^{99 \mathrm{~m}} \mathrm{TC}\right] \mathrm{CC}$ SPECT/CT. However, in the remaining six cancer patients investigated, a solitary I.V. bolus of $20 \mu \mathrm{g}$ or $100 \mu \mathrm{g}$ of CC was injected $1 \mathrm{~h}$ prior to $\left[{ }^{99 \mathrm{~m}} \mathrm{TC}\right] \mathrm{CC}$ administration. Compared to control patients, the serum $\mathrm{T}_{1 / 2}$ clearance of $\left[{ }^{99 \mathrm{~m}} \mathrm{TC}\right] \mathrm{CC}$ decreased from $10 \mathrm{~h}$ to $18 \mathrm{~min}$, and the $\left[{ }^{99 \mathrm{~m}} \mathrm{TC}\right] \mathrm{CC} \mathrm{T} / \mathrm{B}$ ratios on the 4-h SPECT/ $\mathrm{CT}$ images were reported to have improved.

\section{Future Clinical Imaging of Cbl Uptake in Breast Tumors}

The human and murine $\left[{ }^{111} \mathrm{In}\right] \mathrm{AC}$ and $\left[{ }^{99 \mathrm{~m}} \mathrm{TC}\right] \mathrm{CC}$ data suggests that future clinical investigations into imaging $\mathrm{Cbl}$ uptake in breast tumors should employ a pulse of AC or CC at $10-20$ times the RDA ( 24 to $48 \mu \mathrm{g}$ ) at 2 or $24 \mathrm{~h}$ prior to injecting five times the RDA $(12 \mu \mathrm{g})$ of a Cbl radiolabeled analog. With the serum $T_{1 / 2}$ clearance of $\left[{ }^{111} \mathrm{In}\right] \mathrm{AC}$ equaling $7 \mathrm{~min}$, and presuming that a pre-administered pulse of $\mathrm{AC}$ decreases $\left[{ }^{111} \mathrm{In}\right] \mathrm{AC}$ background activity in normal breast tissue, the acquisition of WBP or SPECT/CT images could potentially begin routinely at $2 \mathrm{~h}$ post-tracer injection. The $\left[{ }^{111} \mathrm{In}\right] \mathrm{AC}$ DE data additionally raises the possibility of simply injecting a solitary $24 \mu \mathrm{g}$ bolus of $\left[{ }^{111} \mathrm{In}\right] \mathrm{AC}$, depending upon dosimetry.

Currently no small field of view MBI gamma cameras are capable of imaging [ $\left.{ }^{111} \mathrm{In}\right] \mathrm{AC}$ uptake in a breast tumor < $0.5 \mathrm{~cm}$. However, two new positron labeled $\mathrm{CC}$ analogs and PEM should permit the investigation of $\mathrm{Cbl}$ uptake in smaller breast tumors. The positron labeled $\mathrm{CC}$ analogs, in contrast to $\left[{ }^{111} \mathrm{In}\right] \mathrm{AC}$ and $\left[{ }^{99 \mathrm{~m}} \mathrm{TC}\right] \mathrm{CC}$, have a chelator covalently bonded to the 5 '-hydroxyl group of the deoxyribose moiety within the phosphate sugar that links the alpha ligand (DMB) to the corrin ring $[41,42]$. Both the $\mathrm{Cu}-64-$ and $\mathrm{Zr}$-89-labeled cyanocobalamin analogs have imaged tumor xenografts in vivo. However, only $\left[{ }^{89} \mathrm{Zr}\right] \mathrm{CC}$ has depicted $\mathrm{Cbl}$ uptake in a breast tumor. In the MDA-MB453 breast tumor xenograft, the greatest uptake of $\left[{ }^{89} \mathrm{Zr}\right] \mathrm{CC}$ occurred at $4 \mathrm{~h}$ post I.V. injection.

\section{Cbl Transport and Receptor Proteins in Breast Cancer}

The increased serum concentrations of $\mathrm{HC}$ and/or TC, reportedly observed in $50-65 \%$ of breast cancer patients, were investigated as potential biomarkers. However, the reported variations in $\mathrm{HC}$ and $\mathrm{TC}$ expression within breast cancers only underscore the pleiotropic cytogenetic mechanisms remaining to be decrypted. Recently, several genetic aberrations supporting breast tumor growth were discovered to involve the cytogenetic bands encoding the $\mathrm{Cbl}$ transport/ receptor proteins.

The synthesis of TC in breast tumors was previously posited to be upregulated by ets transcription factors and a $c$ - $m y c$ protein binding to specialized nucleic acid base motifs in the promoter region of the TC gene (TCN2) on chromosome 22q12.2 [43]. More recently, the amplification of the leukemia inhibitory factor (LIF) gene located on 22q.12.2 was discovered to promote the tumorigenesis and metastasis of breast cancer through the AKT-mTOR pathway [44].

Correspondingly, human lactating breast tissue normally upregulates $\mathrm{HC}$ production $\sim 100-400$ times to insure the delivery of $\mathrm{Cbl}$ to nursing newborns [45]. Although the cytogenetic mechanisms triggering the overexpression of $\mathrm{HC}$ in maternal lactating breast tissue and malignant breast tumor cells remain to be elucidated, the CTNND1 gene on 11q12.1, where HC (TCN1) and IF (GIF) genes are encoded, is frequently modified in biologically aggressive breast cancers [46].

Finally, on the cytogenetic bands encoding the $\mathrm{Cbl}$ receptor protein genes: TC-R (CD320) on 19p13.2, MEG (LRP2) on 2q31.1, cubilin (CUBN) on 10p13, amnionless (AMN) on 14q32.32, and ASGP-R (ASGR1 and ASGR2) on $17 \mathrm{p} 13.1$, are foci of gene amplification or mutations that support breast tumor progression, for example, the amplification of DNMT1 on 19p13.2 [47], PDK1 on 2q31.1 [48], CAMK1D on 10p13 [49], and AKT1 on 14q32.32 [50] and mutations of TP53 on $17 \mathrm{p} 13.1$ [51]. Intriguingly, with the concentration of sCD320 increasing in urine and serum during pregnancy, it suggests that the protein fragment may be a biomarker for cellular proliferation [52].

\section{Conclusion}

The uptake of $\mathrm{Cbl}$ in malignant breast tumors can be clinically imaged and biochemically enhanced. Further investigation into targeting the $\mathrm{Cbl}$ metabolic pathway in breast tumors is warranted and could potentially uncover novel theragnostic targets.

Acknowledgements. Dr. H.P.C. Hogenkamp synthesized the AC analog. Dr. Douglas A Collins radiolabeled the AC analog. Linda M. Thorson CNMT performed the $\left[{ }^{111} \mathrm{In}\right] \mathrm{AC}$ plasma and urine clearance assays. Timothy $\mathrm{J}$. Hardyman CNMT acquired the WB/SPECT images and calculated the $\left[{ }^{111} \mathrm{In}\right] \mathrm{AC}$ T/B ratios. Rebecca $\mathrm{M}$. Wilson completed the murine biodistribution studies. Rebecca A. Thompson and Michelle W. Andersen created the illustrations. Rose M. Busta facilitated manuscript production.

\section{Compliance with Ethical Standards}

\section{Conflict of Interest}

Dr. Douglas A Collins and Dr. H.P.C. Hogenkamp have intellectual property related to the radiolabeling of cobalamin that is jointly held by Mayo Clinic and the University of Minnesota. The Cbl research has been funded by the Mayo Foundation and the University of Minnesota.

Open Access This article is distributed under the terms of the Creative Commons Attribution 4.0 International License (http:// creativecommons.org/licenses/by/4.0/), which permits unrestricted use, distribution, and reproduction in any medium, provided you give appropriate credit to the original author(s) and the source, provide a link to the Creative Commons license, and indicate if changes were made. 


\section{References}

1. Plevritis SK, Munoz D, Kurian AW et al (2017) Association of Screening and Treatment with Breast Cancer Mortality by molecular subtype in US women, 2000-2012. J Am Med Assoc 319:154-164

2. Iqbal J, Ginsburg O, Rochon PA, Sun P, Narod SA (2015) Differences in breast cancer stage at diagnosis and cancer-specific survival by race and ethnicity in the United States. J Am Med Assoc 313:165-173

3. Boyd NF, Guo H, Martin LJ, Sun L, Stone J, Fishell E, Jong RA, Hislop G, Chiarelli A, Minkin S, Yaffe MJ (2007) Mammographic density and the risk in detection of breast cancer. N Engl J Med 356:227-236

4. Rhodes D, O'Connor M, Phillips S et al (2005) Molecular breast imaging: a new technique using technetium Tc $99 \mathrm{~m}$ scintimammography to detect small tumors of the breast. Mayo Clin Proc 80:24-30

5. Hsu DFC, Freese DL, Levin CS (2016) Breast-dedicated radionuclide imaging systems. J Nucl Med 57:40S-45S

6. Van Es SC, Venema CM, Glaudemans AWJM et al (2016) Translation of new molecular imaging approaches to the clinical setting: bridging the gap to implementation. J Nucl Med 57:96S-104S

7. Shermis RB, Wilson KD, Doyle MT, Martin TS, Merryman D, Kudrolli H, Brenner RJ (2016) Supplemental breast cancer screening with molecular breast imaging for women with dense breast tissue. AJR 207:450-457

8. Ulaner GA, Riedl CC, Dickler MN, Jhaveri K, Pandit-Taskar N, Weber W (2016) Molecular imaging of biomarkers in breast cancer. J Nucl Med 57:53S-59S

9. Wooley DW (1953) Evidence for the synthesis of vitamin B12 by spontaneous mammary tumors. Proc Nat Acad Sci USA 39:6-18

10. Carmel R, Eisenberg L (1977) Serum vitamin $B_{12}$ and transcobalamin abnormalities in patients with cancer. Cancer 40:1348-1353

11. Rachmilewitz B, Rachilewitz M (1981) Serum transcobalamin-II levels in breast-carcinoma patients. Isr J Med Sci 17:874-878

12. Flohd H, Ullberg $S$ (1968) Accumulation of labelled vitamin $B_{12}$ in some transplanted tumours. Int J Cancer 3:694-699

13. Quadros EV, Sequeira JM (2013) Cellular update of cobalamin: Transcobalamin and the TCbIR/CD320 receptor. Biochemie 95:10081018

14. Quadros EV, Rothenberg SP, Polu S (1988) A specific radioimmunoassay for 5 'deoxyadenosylcobalamin in serum. $\mathrm{Br} \mathrm{J}$ Haematol 69:551-557

15. Brazenas GR, Bartkeviciene VV, Aleksiene AM et al (1979) On some properties of the effect and metabolism of different cobalamins in tumor-bearing rats. In: Zagalak B, Friedrich W (eds) Vitamin $\mathrm{B}_{12}$ Walter de Gruyter, Berlin, pp 1113-1118

16. Hall CA, Colligan PD, Begley JA (1987) Cyclic activity of the receptors of cobalamin bound to transocbalamin II. J Cellular Physiol 133:187-191

17. Collins DA, Hogenkamp HPC (1997) Transcobalamin II receptor imaging via radiolabeled diethylenetriaminepentaacetate cobalamin analogs. J Nucl Med 38:717-723

18. Hogenkamp HPC, Collins DA, Grissom CB, West FG (1999) Diagnostic and therapeutic analogues of cobalamin. In: Banerjee $R$ (ed) Chemistry and biochemistry of B12. John Wiley \& sons, New York, pp 385-410

19. Cruz R, Steyn P, Collins D, Powers B, Urigh J (2011) Radiography, ${ }^{99 \mathrm{~m}} \mathrm{Tc}-\mathrm{HDP}$, and ${ }^{111} \mathrm{In}$ labeled vitamin $\mathrm{B}_{12}$ SPECT of canine osteosarcoma: a comparative study. J Am Animal Hosp Assoc 47:229-235

20. Collins DA, Hogenkamp HPC, Gebhard MW (1999) Tumor imaging via indium 111-labeled DTPA-adenosylcobalamin. Mayo Clin Proc 74:687-691

21. Collins DA, Hogenkamp HPC, O'Connor MK, Naylor S, Benson LM, Hardyman TJ, Thorson LM (2000) Biodistribution of radiolabeled adenosylcobalamin in patients diagnosed with various malignancies. Mayo Clin Proc 75:568-580

22. Greipp PT, Collins DA, Russell SJ, et al. (2006) In-111 DAC is a novel technique to image multiple myeloma (abstract 3488). Blood 108 (11 Part 1): 944 a

23. Benard F, Turcotte E (2005) Imaging in breast cancer: single-photon computed tomography and positron-emission tomography. Breast Cancer Res 7:153-162
24. Stanton SE, Eary JF, Marzbani A, Mankoff D et al (2016) Concurrent SPECT/PET-CT imaging as a method for tracking adoptively transferred T-cells in vivo. J Immunother Cancer 4:27

25. Carmel R, Watkins D, Rosenblatt DS (2015) Megaloblastic Anemia. In: Orkin SH, Fisher DE, Ginsburg D et al (eds) Nathan and Oski's hematology and oncology of infancy and childhood, 8th edn. Saunders, Philadelphia, pp 308-343

26. Frost DV, Fricke HH, Spruth HC (1949) Rat growth assay for vitamin B12. Proc Soc Exp Biol Med 72:102-106

27. Arendt JFB, Nexo E (2012) Cobalamin related parameters and disease patterns in patients with increased serum cobalamin levels. PLoS One 7:e45979

28. Lildballe DL, Mutti E, Birn H, Nexo E (2012) Maximal load of the vitamin B12 transport system: a study on mice treated for four weeks with high-dose vitamin B12 or cobinamide. PLoS One 7:e46657

29. Donaldson RM, rand M, Serfilippi D (1977) Changes in circulating transcobalamin II after injection of cyanocobalamin. N Engl J Med 296:1427-1430

30. Granat M, Rachmilewitz B, Mor-Yosef S et al (1983) Effect of dexamethasone on serum transcobalamin II concentration in women undergoing pelvic surgery. Eur J Clin Pharmacol 25:6221-6624

31. Sysel AM, Valli VE, Nagle RB, Bauer JA (2013) Immunohistochemical quantification of the vitamin B12 transport protein (TCII), cell surface receptor (TCII-R) and Ki-67 in human tumor xenografts. Anticancer Res 33:4203-4212

32. Sysel AM, Valli VE, Bauer JA (2014) Immunohistochemical quantification of the cobalamin transport protein, cell surface receptor and Ki-67 in naturally occurring canine and feline malignant tumors and in adjacent normal tissues. Oncotarget 6:2331-2348

33. Chlon TM, Taffany DA, Welsh J, Rowling MJ (2008) Retinoids module expression of the endocytic partners megalin, cubilin, and disabled-2 and uptake of vitamin D-binding protein in human mammary cells. Nutrition 138:1323-1328

34. Christensen EI, Birn H (2002) Megalin and cubulin: multifunctional endocytic receptors. Nature 3:258-268

35. Kozyrak R, Gofflot F (2007) Multiligand endocytosis and congenital defects: roles of cubilin, megalin and amnionless. Curr Pharm Des 13:3038-3046

36. Arora K, Sequeira J, Quadros E (2017) Maternofetal transport of vitamin B12: role of TCb1R/CD320 and megalin. FASEB 31:30983106

37. Waibel T, Treichler H, Schaefer NG et al (2008) New derivatives of vitamin B12 show preferential targeting of tumors. Cancer Res 68:2904-2911

38. Mu J-Z, Tang L-H, Alpers DH (1993) Asialoglycoprotein receptor mRNAs are expressed in most extrahepatic rat tissues during development. Am J Phys 264:G752-G762

39. Wuerges J, Geremia S, Randaccio L (2007) Structural study on ligand specificity of human vitamin B12 transporters. Biochem J 403:431440

40. Sah B-R, Schibli R, Waibel R et al (2014) Tumor imaging in patients with advanced tumors using a new ${ }^{99 \mathrm{~m}} \mathrm{Tc}$-radiolabeled vitamin B12 derivative. J Nucl Med 55:43:43-43:49

41. Ikotun OF, Marquez BV, Fazen $\mathrm{CH}$ et al (2014) Investigation of a vitamin B12 conjugate as a PET imaging probe. ChemMedChem 9:1244-1251

42. Akhila N, Kuda-Wedagedara W, Workinger JL et al (2017) ${ }^{89} \mathrm{Zr}-$ cobalamin PET tracer: synthesis, cellular uptake, and use for tumor imaging. ACS Omega 2:6314-6320

43. Regec A, Quadros EV, Platica O, Rothenberg SP (1995) The cloning and characterization of the human transcobalamin II gene. Blood 85:2711-2719

44. Li X, Yang Q, Yu H, Wu L, Zhao Y, Zhang C, Yue X, Liu Z, Wu H, Haffty BG, Feng Z, Hu W (2014) LIF promotes tumorigenesis and metastasis of breast cancer through the AKT-mTOR pathway. Oncotarget 5:788-801

45. Lildballe Dl HTF, Allen LH, Nexo E (2009) High concentrations of haptocorrin interfere with routine measurement of cobalamins in human serum and milk. A problem and its solution. Clin Chem Lab Med 47:182-187

46. Schackmann R, Klarenbeek S, Vlug E et al (2013) Loss of p120catenin induces metastatic progression of breast cancer by inducing Anoikis resistance and augmenting growth factor receptor signaling. Cancer Res 73:4937-4949 
47. Pathania R, Ramachandran S, Elangovan S, Padia R, Yang P, Cinghu S, Veeranan-Karmegam R, Arjunan P, Gnana-Prakasam JP, Sadanand F, Pei L, Chang CS, Choi JH, Shi H, Manicassamy S, Prasad PD, Sharma S, Ganapathy V, Jothi R, Thangaraju M (2015) DNMT1 is essential for mammary and cancer stem cell maintenance and tumorigenesis. Nat Commun 6:6910

48. Du J, Yang M, Chen S et al (2016) PDK1 promotes tumor growth and metastasis in a spontaneous breast cancer model. Oncogene 35:3314 3323

49. Bergamaschi A, Kim YH, Kwei KA, la Choi Y, Bocanegra M, Langerød A, Han W, Noh DY, Huntsman DG, Jeffrey SS, BørresenDale AL, Pollack JR (2008) CAMK1D amplification implicated in epithelial-mesenchymal transition in basal-like breast cancer. Mol Oncol 2:327-339
50. Riggio M, Perrone MC, Polo ML et al (2017) AKT1 and AKT2 isoforms play distinct roles during breast cancer progression through the regulation of specific downstream proteins. Nature: Scientific Reports 7:44244

51. Liu Y, Chen C, Xu Z, Scuoppo C, Rillahan CD, Gao J, Spitzer B, Bosbach B, Kastenhuber ER, Baslan T, Ackermann S, Cheng L, Wang Q, Niu T, Schultz N, Levine RL, Mills AA, Lowe SW (2016) Deletions linked to TP53 loss drive cancer through p53-independent mechanisms. Nature 531:471-475

52. Abuyaman O, Andreasen BH, Kronberg C et al (2013) The soluble receptor for vitamin $\mathrm{B} 12$ uptake ( $\mathrm{sCD} 320)$ increases during pregnancy and occurs in higher concentration in urine than in serum. PLoS One 8:e 73110 